\section{Effects of Trinexapac-Ethyl on the Salinity Tolerance of Two Ultradwarf Bermudagrass Cultivars}

\author{
Christian M. Baldwin, Haibo Liu, ${ }^{1}$ Lambert B. McCarty, and \\ William L. Bauerle \\ Department of Horticulture, D-136Poole Agriculture Center, Clemson University, \\ Clemson, SC 29634-0319
}

Joe E. Toler

Department of Applied Economics and Statistics, Clemson University, Clemson, SC 29634-0319

Additional index words. 'Champion', 'TifEagle', plant growth regulator, Primo, turf quality, nutrients, rooting

Abstract. Studies on bermudagrasses (Cynodon spp.) have demonstrated variability in salinity response among species and cultivars. However, information on ultradwarf bermudagrass cultivars in relative salinity tolerance associated with trinexapac-ethyl (TE) [4-(cyclopropyl- $\alpha$-hydroxy-methylene)-3,5-dioxocyclohexanecarboxylic acid ethyl ester], a cyclohexanedione type II plant growth regulator (PGR), remains unknown. Therefore, two replicated greenhouse studies were conducted to determine the salinity tolerance of two ultradwarf bermudagrass cultivars treated with TE on turfgrass quality (TQ), total root biomass, and root and shoot tissue nutrient concentration. Turfgrasses included 'TifEagle' and 'Champion'bermudagrass (Cynodon dactylon (L.) Pers. $\times$ C. transvaalensis Burtt-Davy). Daily sodium chloride $(\mathrm{NaCl})$ exposure was $0,12.90(8,000 \mathrm{ppm}), 25.80(16,000 \mathrm{ppm})$, and $38.71 \mathrm{dS} \cdot \mathrm{m}^{-1}(24,000 \mathrm{ppm})$. Biweekly TE applications (active ingredient $0.02 \mathbf{~ k g} \cdot \mathbf{h a}^{-1}$ ) were initiated 2 weeks after salinity exposure. 'Champion' was more salt-tolerant than 'TifEagle' based on TQ and root mass. At 12.90, 25.80 , and $38.71 \mathrm{dS} \cdot \mathrm{m}^{-1} \mathrm{of} \mathrm{NaCl}$, nontreated (without TE) 'Champion' consistently outperformed nontreated 'TifEagle' with greater TQ on most rating dates. At $12.90 \mathrm{dS} \cdot \mathrm{m}^{-1}$, TE treated 'Champion' (8.0) had greater TQ than nontreated 'TifEagle' (6.1) at week 10. Regardless of TE application, after 2 weeks of applying 25.80 $\mathrm{dS} \cdot \mathrm{m}^{-1}$ of $\mathrm{NaCl}$, both cultivars fell below acceptable TQ $(<7)$. When averaged across all salinity treatments, applying TE four times at $0.02 \mathrm{~kg} \cdot a . i$./ha in two week intervals enhanced root growth for both bermudagrass cultivars by $25 \%$. Also, both cultivars decreased root mass as salinity levels increased. Non TE-treated 'TifEagle' had $56 \%$ and $40 \%$ less root and shoot Na uptake compared to TE treated cultivars at $25.80 \mathrm{dS} \cdot \mathrm{m}^{-1}$. In conclusion, the two bermudagrass cultivars responded differently when exposed to moderate levels of $\mathrm{NaCl}$.

Global demand for fresh potable water doubles every 20 years, therefore, turfgrass managers continuously seek alternative water sources (Duncan and Carrow, 2000). Salt water exposure often weakens turfgrasses and reduces growth to a point of unacceptable quality. Current cultural practices to relieve salinity stress include planting salt-tolerant grasses, leaching excess salts, modifying soils with various amendments to replace or leach $\mathrm{Na}$ and $\mathrm{Cl}$ from the soil, and enhancing soil drainage with subsurface drainage (McCarty, 2005).

Two major causes of plant growth inhibition under salinity stress are osmotic stress (osmotic inhibition of plant water absorption) and specific ion effects (Marcum, 2002). Generally, plants absorb water and nutrients by osmosis. As salts enter the soil profile, water uptake is inhibited as the osmotic gradient changes (Harivandi et al., 1992). At lower salt concentrations, an osmotic adjustment may allow the plant to continue water uptake, maintain cell turgor, cell expansion, and other metabolic activities (Carrow and Duncan,

Received for publication 19 Oct. 2005. Accepted for publication $15 \mathrm{Dec}$. 2005. Contribution of the Clemson University Experiment Station.

${ }^{1}$ Corresponding author; e-mail haibol@clemson.edu.
Many studies have been conducted to determine the salinity tolerance of warm-season turfgrasses (Ackerson and Youngner, 1975; Dudeck et al., 1983; Dudeck and Peacock, 1993; Marcum et al., 1998; Qian et al., 2000). However, the salinity tolerance of two popular ultradwarf hybrid bermudagrass cultivars used on golf course putting greens, 'TifEagle' and 'Champion', is unknown.

Trinexapac-ethyl is a foliar absorbed cyclohexanedione Type II gibberellic acid (GA) inhibiting PGR (Fagerness and Penner, 1998) which effectively reduces leaf elongation. Trinexapac-ethyl inhibits cell elongation late in the mevalonic acid pathway by stopping the conversion $\mathrm{GA}_{20}$ to $\mathrm{GA}_{1}$ (Fagerness and Penner, 1998). Typical turfgrass responses to TE may include a darker green color, increased shoot density, and smaller, more compact leaves.

The primary absorption site for TE is the leaf sheaths surrounding the compressed stem and the plant crown, while roots absorb only 5\% after $24 \mathrm{~h}$ (Fagerness and Penner, 1998). Therefore, any inhibition of root growth when applying TE is correlated to the effects of reduced shoot growth. In a nitrogen use study, Fagerness et al. (2004) stated TE application does not increase nitrate leaching in 'Tifway' bermudagrass, but increases fertility recovery when the active ingredient is applied twice at $0.11 \mathrm{~kg} \cdot \mathrm{ha}^{-1}$ in 4 -week intervals.

Until the release of TE, PGR use on high-quality turf was limited due to potential phytotoxic effects on warm and cool-season turfgrasses (Shepard, 2002). Undesirable characteristics included phytotoxicity of treated leaves, reduced recuperative ability, and increased weed pressure due to reduced competition from treated turfgrasses (McCarty, 2005). Initially, TE was developed to reduce mowing frequency, however, recent studies have investigated TE's influence on improving water use efficiency, heat tolerance, and shade tolerance (Bunnell et al., 2005; Steinke and Stier, 2003; Zhang et al., 2003). Trinexapacethyl provides a more compact, smaller leaf blade (reducing transpiration) and a more dense turf (reducing soil evaporation). Applying TE to a salt-stressed turf may enhance quality by reducing evapotranspiration which prolongs the availability of soil water.

In this study, the objectives were 1) to compare the salt tolerance of 'TifEagle' and 'Champion' bermudagrass cultivars, 2) to evaluate the effect of biweekly TE applications on turfgrass quality and root biomass, and 3) to determine the interactive effects on $\mathrm{P}, \mathrm{K}, \mathrm{Mg}, \mathrm{Ca}$, and $\mathrm{Na}$ concentrations in above and belowground growth following TE and salt exposure.

\section{Materials and Methods}

This research included two repeated studies. Study I was conducted from 9 Jan. 2004 to 19 Mar. 2004. Greenhouse conditions averaged $23.3^{\circ} \mathrm{C} / 21.1^{\circ} \mathrm{C}$ day/night temperature and $56 \%$ relative humidity. Study II was conducted from 19 Jan. 2004 to 29 Mar. 2004. Greenhouse conditions averaged day/night temperature of 24.4 ${ }^{\circ} \mathrm{C} / 20.5^{\circ} \mathrm{C}$ and $60 \%$ relative humidity.

Each study consisted of four treatments 
including a control with each cultivar replicated four times in a randomized complete block design. Plugs for the study were harvested from field research plots located on the Clemson University campus and transplanted into pots with $85 \%$ sand and $15 \%$ peat as growth media. Pot dimensions were $15.24 \mathrm{~cm}$ in height and $11.43 \mathrm{~cm}$ in diameter. Following potting, plugs were allowed to break dormancy and establish 1 month before initial treatments. Fertility was provided as nitrogen at $49 \mathrm{~kg} \cdot \mathrm{ha}^{-1}$ biweekly using a 16-4-8 fertilizer (including micronutrients as: $\mathrm{Ca} 6$; $\mathrm{Mg}$ 3; $\mathrm{S} 9$; $\mathrm{B} 0.06 ; \mathrm{Cu} 0.03$; Fe 0.3; Mn 0.15; Mo 0.0015; and Zn 0.15 kg $\mathrm{ha}^{-1}$ ). Pots were mowed daily at $0.38 \mathrm{~cm}$ with clippings removed.

Salinity levels were $0,12.90(8,000 \mathrm{ppm})$, $25.80(16,000 \mathrm{ppm})$, and $38.71 \mathrm{dS} \cdot \mathrm{m}^{-1}(24,000$ ppm). Appropriate $\mathrm{NaCl}$ levels were applied daily in $50 \mathrm{~mL}$ (equaling an irrigation of 2.7 $\mathrm{mm}$ ) deionised distilled water. Trinexapacethyl applications were initiated 2 weeks after salinity exposure and applied four times in two week intervals at the active ingredient of 0.02 $\mathrm{kg} \cdot \mathrm{ha}^{-1}$. The emulsifiable concentrate $(11.3 \%$ a.i.) of TE was used.

Since Study I and Study II were repeated studies, data collection was similar. Turf quality ratings were recorded weekly based on color, density, texture, and uniformity of the bermudagrass surface. Quality was visually evaluated from 1 to 9,1 = brown, dead turf, $7=$ minimal acceptable turf, $9=$ ideal green, healthy turf. Clippings were harvested at week 10 for nutrient analysis. Roots were extracted from the soil and thoroughly washed until all soil was removed and then clipped from the base of the shoot tissue. Fresh weight of roots were then placed in an oven at $80.0{ }^{\circ} \mathrm{C}$ and dried for 48 hours. Once dried, samples were weighed to determine total root biomass. Roots and clippings were analyzed at the Clemson University testing laboratory for $\mathrm{P}, \mathrm{K}, \mathrm{Ca}, \mathrm{Mg}$, and $\mathrm{Na}$ concentration.

Nutrient analysis. For cation concentration determination and $\mathrm{Na}$ analysis, nitric acid $\left(\mathrm{HNO}_{3}\right)+30 \%$ peroxide $\left(\mathrm{H}_{2} \mathrm{O}_{2}\right)$ was used in a wet ash procedure. Plant material $(0.50 \mathrm{~g})$ was weighed and placed into a $100 \mathrm{~mL}$ digestion tube with $5 \mathrm{~mL}$ of $\mathrm{HNO}_{3}$. Each digestion tube was heated at $125^{\circ} \mathrm{C}$ for $1 \mathrm{~h}$. Once tubes were heated and allowed to cool, $3 \mathrm{~mL}$ of $30 \% \mathrm{H}_{2} \mathrm{O}_{2}$ was placed in each sample and heated at 200 ${ }^{\circ} \mathrm{C}$ or until samples dried. Plant tissue was then removed from the digestion tubes by adding $10 \mathrm{~mL}$ of $1: 10 \mathrm{HNO}_{3}$ and diluted in $50 \mathrm{~mL}$ of deionized water and shaken vigorously. An inductively coupled plasma (ICP) autosampler (61E, Thermo Jarrell-Ash, Franklin, Mass.) was used to determine nutrient levels (Baldwin et al., 2005; Erickson et al., 2005).

Data analysis. All statistical computations were conducted using analysis of variance (ANOVA) within the StatisticalAnalysis System (SAS Institute, 1999). Due to limited root and shoot growth at the $38.71 \mathrm{dS} \cdot \mathrm{m}^{-1}$ treatment, only the control, 12.50 , and $25.80 \mathrm{dS} \cdot \mathrm{m}^{-1}$ treatments were analyzed for nutrient concentrations. Data from both studies were combined as Study I $\times$ Study II interactions were not significant. Regression analysis was used to determine
TQ growth response curves and to predict TQ scores. Interactions for root mass were not significant, therefore, only salinity, cultivar, and TE effects are reported. However, interactions for nutrient concentrations were significant, therefore, means were separated by Fisher's least significant difference (LSD) test. An alpha of 0.05 was used for all data comparisons.

\section{Results and Discussion}

Turfgrass quality (TQ). Unlike yield production crops, the most important measurement for turfgrass managers is TQ. Within each cultivar, TE improved TQ by providing a more dense turf with a darker green appearance (Fig. 1). At week 10, TE treated 'Champion' (8.8) had greater TQ than nontreated 'Champion' (7.1), while TE treated 'TifEagle' (7.8) had greater
TQ than nontreated TE (7.0). Also, TE treated 'Champion' (8.8) had a greater TQ than nontreated 'TifEagle' (7.0) at week 10.

After 10 weeks of applying $12.90 \mathrm{dS} \cdot \mathrm{m}^{-1}$ of $\mathrm{NaCl}$, TE treated 'Champion' produced acceptable TQ (>7) ratings (Fig. 2). Lee et al. (2004) noted 'Tifgreen' and 'Tifway' bermudagrass tolerated 10 to $15 \mathrm{dS} \cdot \mathrm{m}^{-1}$ of $\mathrm{NaCl}$ without TE. Without TE, at $12.90 \mathrm{dS} \cdot \mathrm{m}^{-1}$, 'Champion' $(\approx 6.9)$ consistently outperformed 'TifEagle' $(\approx 5.7)$ at weeks 6 and 8 . Significant improvements for TE treated 'TifEagle' $(\approx 7.0)$ were noted compared to nontreated TE $(\approx 5.9)$ at weeks 8 and 10 .

At $25.80 \mathrm{dS} \cdot \mathrm{m}^{-1}$, all cultivars, regardless of TE application, decreased in TQ (Fig. 3). Although all quality ratings were below 7.0, similar trends continued as nontreated 'Champion' had higher TQ scores than nontreated 'TifEagle' through week 10 . Overall, at $25.80 \mathrm{dS} \cdot \mathrm{m}^{-1}, \mathrm{TE}$
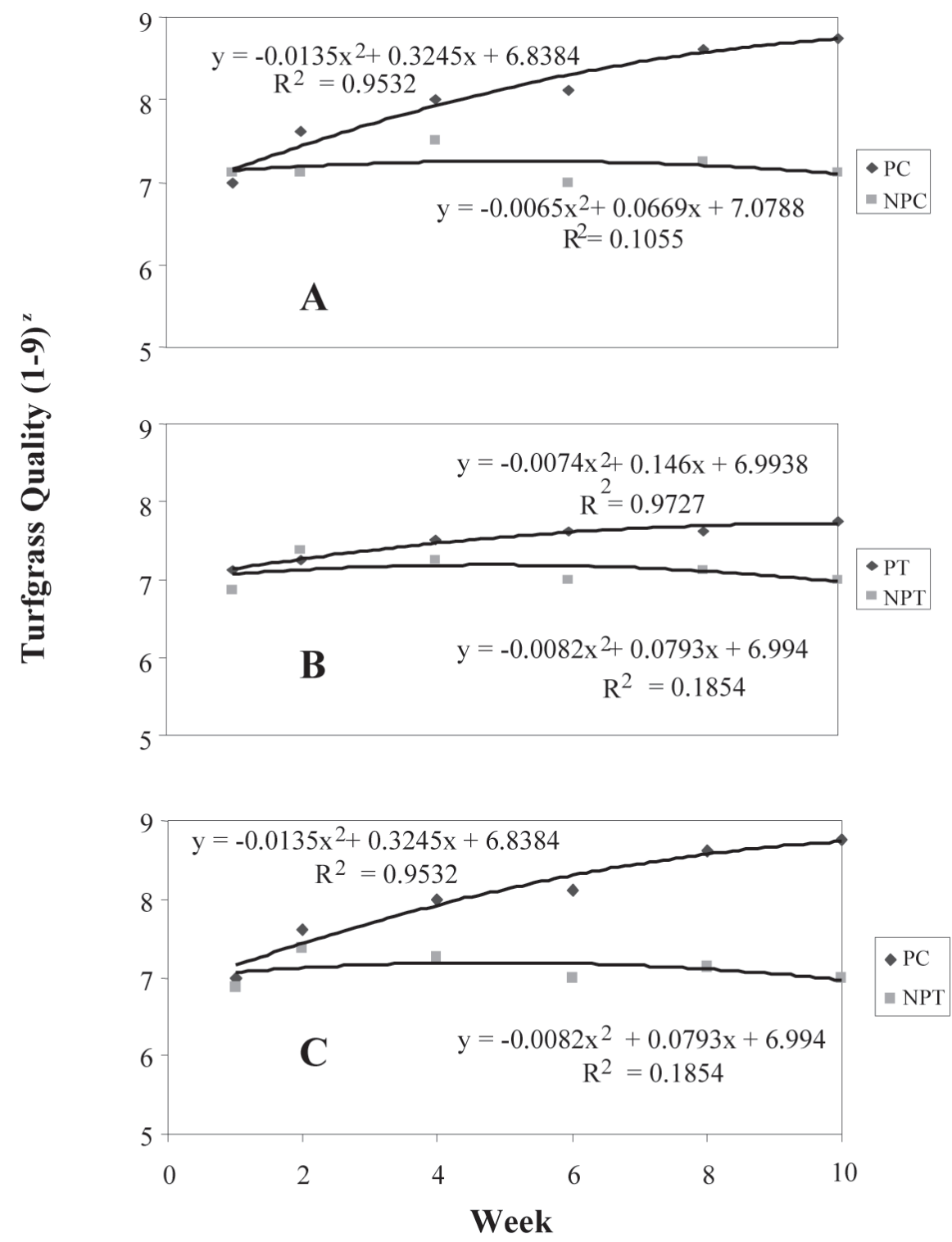

Fig. 1. Comparing four bi-weekly trinexapac-ethyl $\left(0.02 \mathrm{~kg} \cdot \mathrm{ha}^{-1}\right)$ applications beginning at week 2 and then reapplied every 2 weeks until week 8 on turfgrass quality of 'Champion' and 'TifEagle' bermudagrass without salinity: (A) PC vs. NPC, (B) PT vs. NPT, and (C) PC vs. NPT. PT = 'TifEagle' with trinexapac-ethyl, $\mathrm{PC}=$ 'Champion' with trinexapac-ethyl, NPT = 'TifEagle' without trinexapac-ethyl, NPC = 'Champion' without trinexapac-ethyl. Lines within each graph are statistically different at $p \leq 0.05$.

${ }^{2}$ Turfgrass quality based on a scale of 1 to $9,1=$ brown/dead turf, $7=$ minimally acceptable turf, $9=$ ideal green, healthy turf. 
did not have a similar impact within cultivars as with the lower salt treatment $\left(12.90 \mathrm{dS} \cdot \mathrm{m}^{-1}\right)$.

Regression analysis predicted TE treated 'TifEagle' can tolerate $6.00 \mathrm{dS} \cdot \mathrm{m}^{-1}(4,278 \mathrm{ppm})$, TE treated 'Champion' can tolerate $15.78 \mathrm{dS} \cdot \mathrm{m}^{-1}$ (9,783 ppm), nontreated 'TifEagle' can tolerate $3.20 \mathrm{dS} \cdot \mathrm{m}^{-1}(1,984 \mathrm{ppm})$ and nontreated 'Champion' can tolerate $8.70 \mathrm{dS} \cdot \mathrm{m}^{-1}(5,394 \mathrm{ppm})$ of salt before dropping below an acceptable TQ rating of 7 (Fig. 4). Therefore, based on TQ when TE treated, this study suggests 'Champion' is tolerant to salinity levels less than $15.78 \mathrm{dS} \cdot \mathrm{m}^{-1}$, while 'TifEagle' is tolerant to salinity levels of less than $6.00 \mathrm{dS} \cdot \mathrm{m}^{-1}$.

Root biomass. Previous research indicates TE does not reduce root biomass for both warm-season and cool-season turfgrasses when exposed to non-saline pressure (Ervin and Koski, 2001; Fagerness and Yelverton, 2001; Fagerness et al., 2004; McCarty et al., 2004). This short-term greenhouse study indicated four applications of TE applied at $0.02 \mathrm{~kg} \cdot a . i . / \mathrm{ha}$ for both cultivars averaged across all salinity treatments in two week intervals enhanced root growth by $25 \%$ (Fig. 5). Additionally, when comparing cultivar rooting, 'Champion' produced significantly greater total rootbiomass than 'TifEagle' averaged for all salinity and TE treatments (treated and nontreated) (Fig. 6). Increased root biomass under slight or moderate salinity stresses (Dudeck etal., 1983; Harivandi, 1992) may be one of the adaptive mechanisms by increasing the root absorbing surface to take up for more water. However, reduced root biomass was found as salinity treatments increased compared to the control in this study (Fig. 7). This may indicate that under low mowing putting green heights, with reduced photosynthesis, root reduction may likely occur in response to salinity stress above adaptive levels.

Nutrient analysis. Sodium $(\mathrm{Na})$ levels increased 7 to 13 times in root tissue and 9 to 17 times in shoot tissue for both cultivars at the $25.80 \mathrm{dS} \cdot \mathrm{m}^{-1}$ treatment compared to the control (Table 1). Dudeck and Peacock (1993) reported 7 to 14 times greater uptake of $\mathrm{Na}$ at $43 \mathrm{dS} \cdot \mathrm{m}^{-1}$ in 'FSP-1' and 'FSP-3' seashore paspalum (Paspalum vaginatum Swartz.) and 'Tifway II' bermudagrass. In this research, both TE treated and nontreated cultivars averaged $261 \%$ greater $\mathrm{Na}$ in shoot tissue rather than root tissue at $25.80 \mathrm{dS} \cdot \mathrm{m}^{-1}$. This was expected as initial symptoms of salt stress include reduced shoot growth by turf thinning and leaf tip burning. At $25.80 \mathrm{dS} \cdot \mathrm{m}^{-1}$, compared to TE treated 'TifEagle' bermudagrass, nontreated 'TifEagle' had a $55 \%$ and $40 \%$ Na decrease in root and shoot tissue. Minimal $\mathrm{Na}$ reductions $(\approx 6 \%)$ occurred in root and shoot tissue for TE treated 'Champion' bermudagrass compared to nontreated at $25.80 \mathrm{dS} \cdot \mathrm{m}^{-1}$.

At 12.90 and $25.80 \mathrm{dS} \mathrm{m}^{-1}$, both TE treated ad nontreated cultivars shoot phosphorus (P) and potassium $(\mathrm{K})$ levels were reduced an average $44 \%$ and $154 \%$, respectively (Table 2). Similar reductions in K root tissue also occurred at $25.80 \mathrm{dS} \cdot \mathrm{m}^{-1}$, however, root $\mathrm{P}$ levels were unaffected by salinity or TE applications. These results are similar to Dudeck et al. (1983) which reported a reduction in $\mathrm{K}$ as $\mathrm{Na}$ levels increased in bermudagrass cultivars. Qian et al. (2000) noted a reduction in shoot $\mathrm{K}$ and an increase in shoot $\mathrm{Na}$ concentration in zoysiagrass cultivars at $42.5 \mathrm{dS} \cdot \mathrm{m}^{-1}$. In general, as $\mathrm{NaCl}$ treatments increased to $25.80 \mathrm{dS} \cdot \mathrm{m}^{-1}$, Ca and $\mathrm{Mg}$ reductions occurred in both root and shoot tissues (Table 3). Similar results were reported by Dudeck and Peacock (1993). Unlike P and $\mathrm{K}$, TE treated turfgrass significantly enhanced $\mathrm{Ca}$ and $\mathrm{Mg}$ levels in shoot tissue compared to nontreated turf (Table 3). At 12.90 and 25.80 $\mathrm{dS} \cdot \mathrm{m}^{-1}, \mathrm{TE}$ treated 'TifEagle' bermudagrass had $57 \%$ and $77 \%$ and TE treated 'Champion' had $25 \%$ and $20 \%$ greater Ca levels in shoot tissue
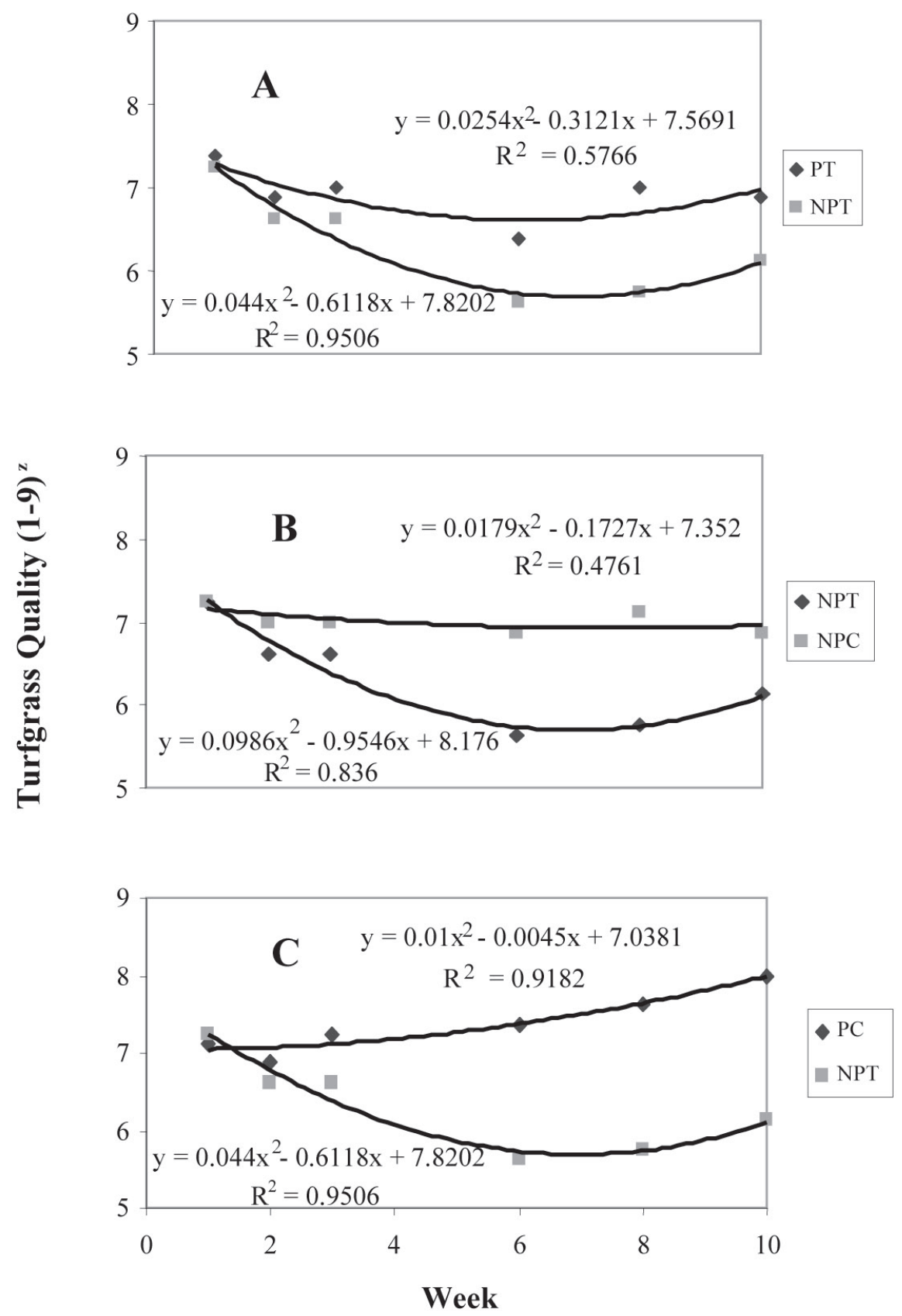

Fig. 2. Comparing salinity $\left(12.90 \mathrm{dS} \cdot \mathrm{m}^{-1}\right)$ and four biweekly trinexapac-ethyl $\left(0.02 \mathrm{~kg} \cdot \mathrm{ha}^{-1}\right)$ applications beginning at week 2 and then reapplied every 2 weeks until week 8 on turfgrass quality of 'Champion' and 'TifEagle' bermudagrass : (A) PT vs. NPT, (B) NPT vs. NPC, and (C) PC vs. NPT. PT = 'TifEagle' with trinexapac-ethyl, PC $=$ 'Champion' with trinexapac-ethyl, NPT = 'TifEagle' without trinexapac-ethyl, NPC = 'Champion' without trinexapac-ethyl. Lines within each graph are statistically different at $p \leq 0.05$.

$\overline{{ }^{2} \text { Turfgrass quality based on a scale of } 1 \text { to } 9,1=\text { brown/dead turf, } 7=\text { minimally acceptable turf, } 9=\text { ideal }}$ green, healthy turf. 

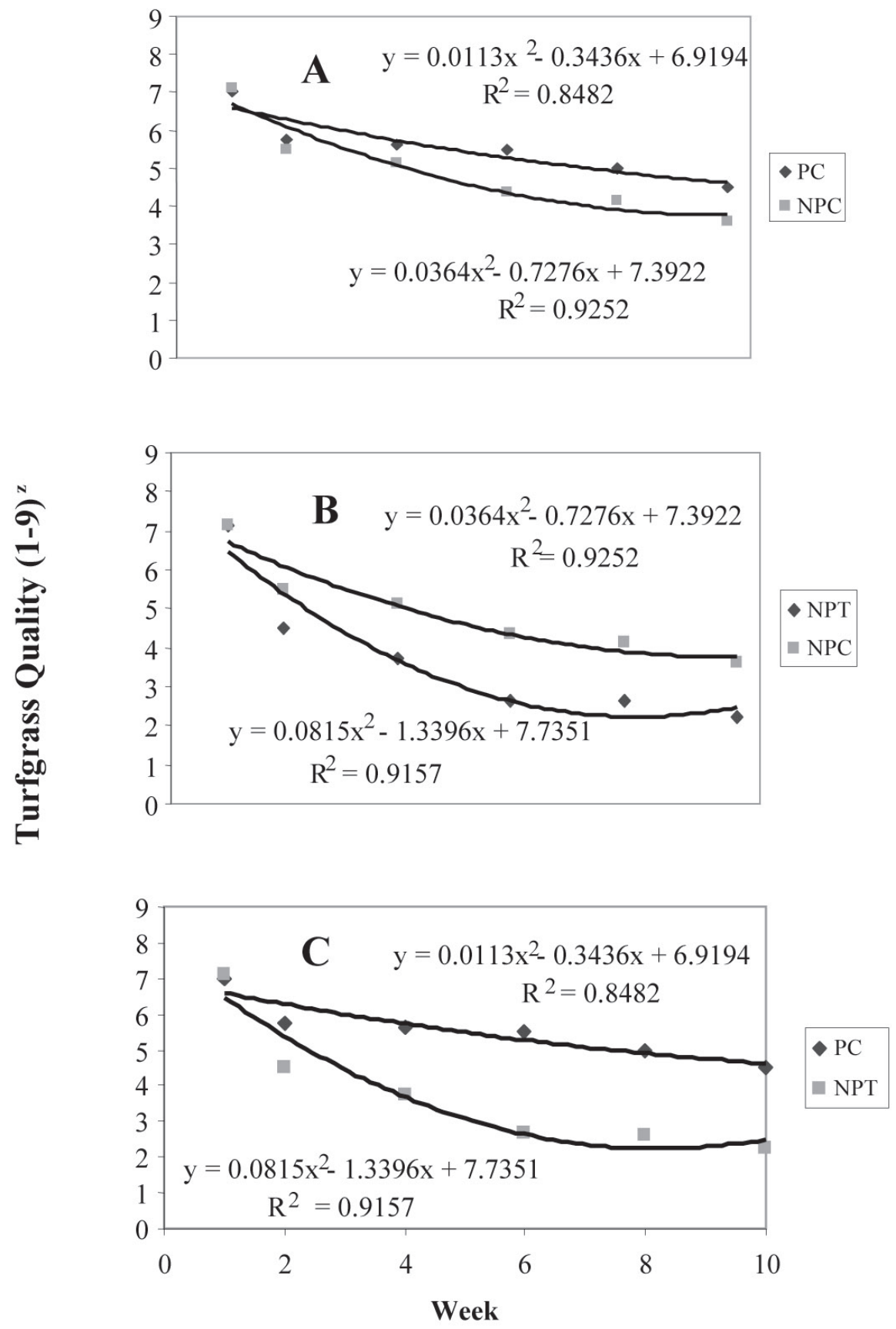

Fig. 3. Comparing salinity $\left(25.80 \mathrm{dS} \cdot \mathrm{m}^{-1}\right)$ and four bi-weekly trinexapac-ethyl $\left(0.02 \mathrm{~kg} \cdot \mathrm{ha}^{-1}\right)$ applications beginning at week 2 and then reapplied every 2 weeks until week 8 on turfgrass quality of 'Champion' and 'TifEagle' bermudagrass : (A) PC vs. NPC, (B) NPT vs. NPC, and (C) PC vs. NPT. PT = 'TifEagle' with trinexapac-ethyl, PC = 'Champion' with trinexapac-ethyl, NPT = 'TifEagle' without trinexapac-ethyl, NPC = 'Champion' without trinexapac-ethyl. Lines within each graph are statistically different at $p \leq 0.05$.

${ }^{2}$ Turfgrass quality based on a scale of 1 to $9,1=$ brown/dead turf, $7=$ minimally acceptable turf, $9=$ ideal green, healthy turf.

can displace $\mathrm{Ca}^{+2}$ oncation exchange sites in the soil and also from the cell membrane reducing cell membrane ion exclusion and selective transport (Carrow and Duncan, 1998). Potassium in turfgrasses may be depressed due to existing $\mathrm{Na}^{+}$and added $\mathrm{Ca}^{+2}$. This study agrees with other reviews or reports (Carrow and Duncan, 1998; Harivandi, 1992; Marcum, 1999; Lee et al., 2004) that under salinity stress, additional applications of $\mathrm{Ca}, \mathrm{K}, \mathrm{Mg}$, and $\mathrm{P}$ may reduce ion imbalance in the soil.

\section{Conclusions}

'Champion' and 'TifEagle' bermudagrass are tolerant to salt levels less than 15.78 and $6.00 \mathrm{dS} \cdot \mathrm{m}^{-1}$ with TE application, respectively. Without TE, 'TifEagle' (6.1) had lower TQ than 'Champion' (6.9) after 10 weeks of applying $12.90 \mathrm{dS} \cdot \mathrm{m}^{-1}$. Also, at the $12.90 \mathrm{dS} \cdot \mathrm{m}^{-1}$ treatment, TE treated 'Champion' was the only turfgrass with an acceptable TQ rating $(>7)$ after 10 weeks. Salinity impacted root growth 

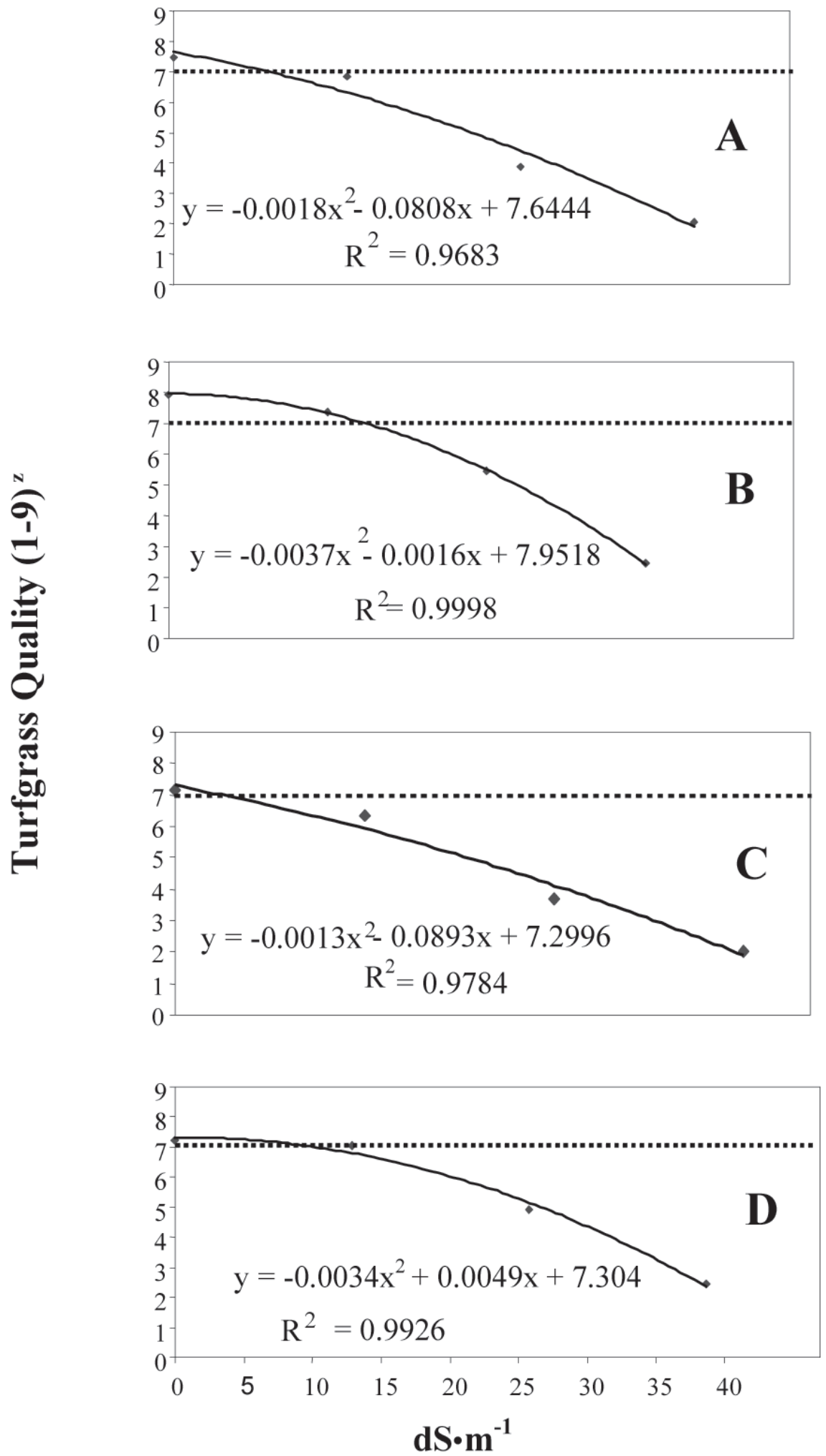

Fig. 4. Predicted turfgrass quality responses of (A) PT, (B) PC, (C) NPT, and (D) NPC to various salinity levels. Abbreviations: PT = 'TifEagle' with trinexapac-ethyl, $\mathrm{PC}=$ 'Champion' with trinexapac-ethyl, NPT $=$ 'TifEagle' without trinexapac-ethyl, NPC $=$ 'Champion' without trinexapac-ethyl. Lines indicate minimal acceptable turf quality (7).

${ }^{2}$ Turfgrass quality based on a scale of 1 to $9,1=$ brown/dead turf. $7=$ minimally acceptable turf, $9=$ ideal green, healthy turf.

within each cultivar. Trinexapac-ethyl application increased root growth by $25 \%$ for both cultivars. In addition, salinity levels impacted nutrient levels in both cultivars. Sodium con- centration increased an average $261 \%$ in shoot tissue compared to root tissue for TE treated and nontreated cultivars. Reductions in plant tissue $\mathrm{P}, \mathrm{K}, \mathrm{Mg}$, and $\mathrm{Ca}$ concentrations in both 


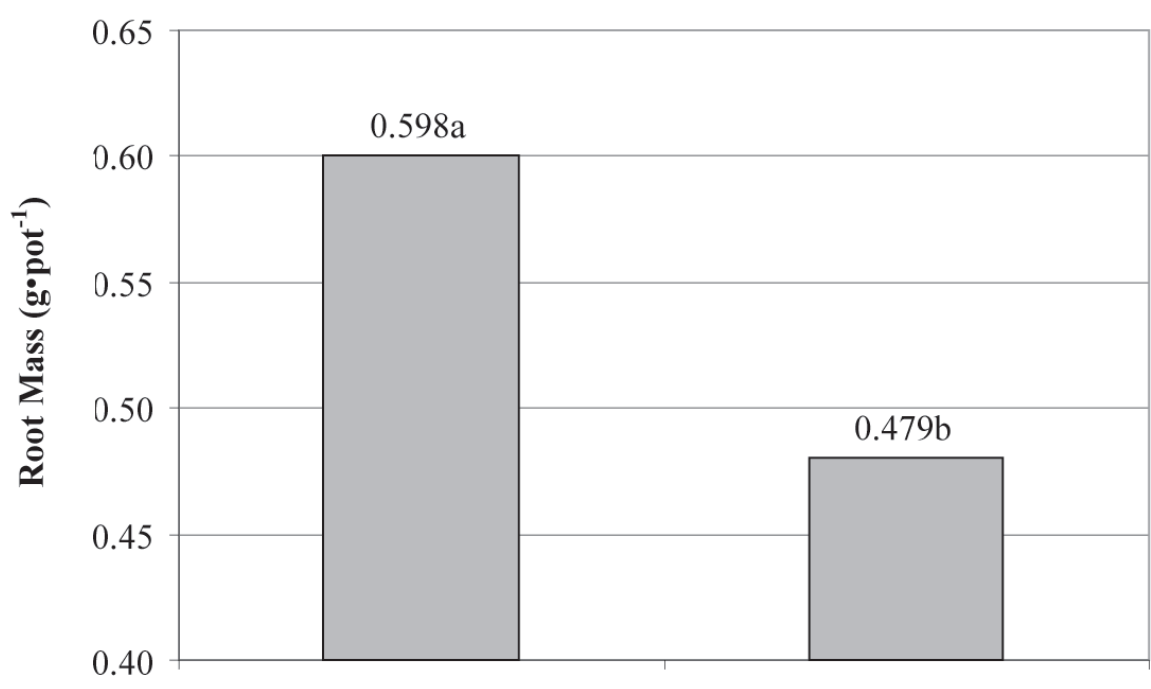

Trinexapac-ethyl ${ }^{\mathrm{z}}$
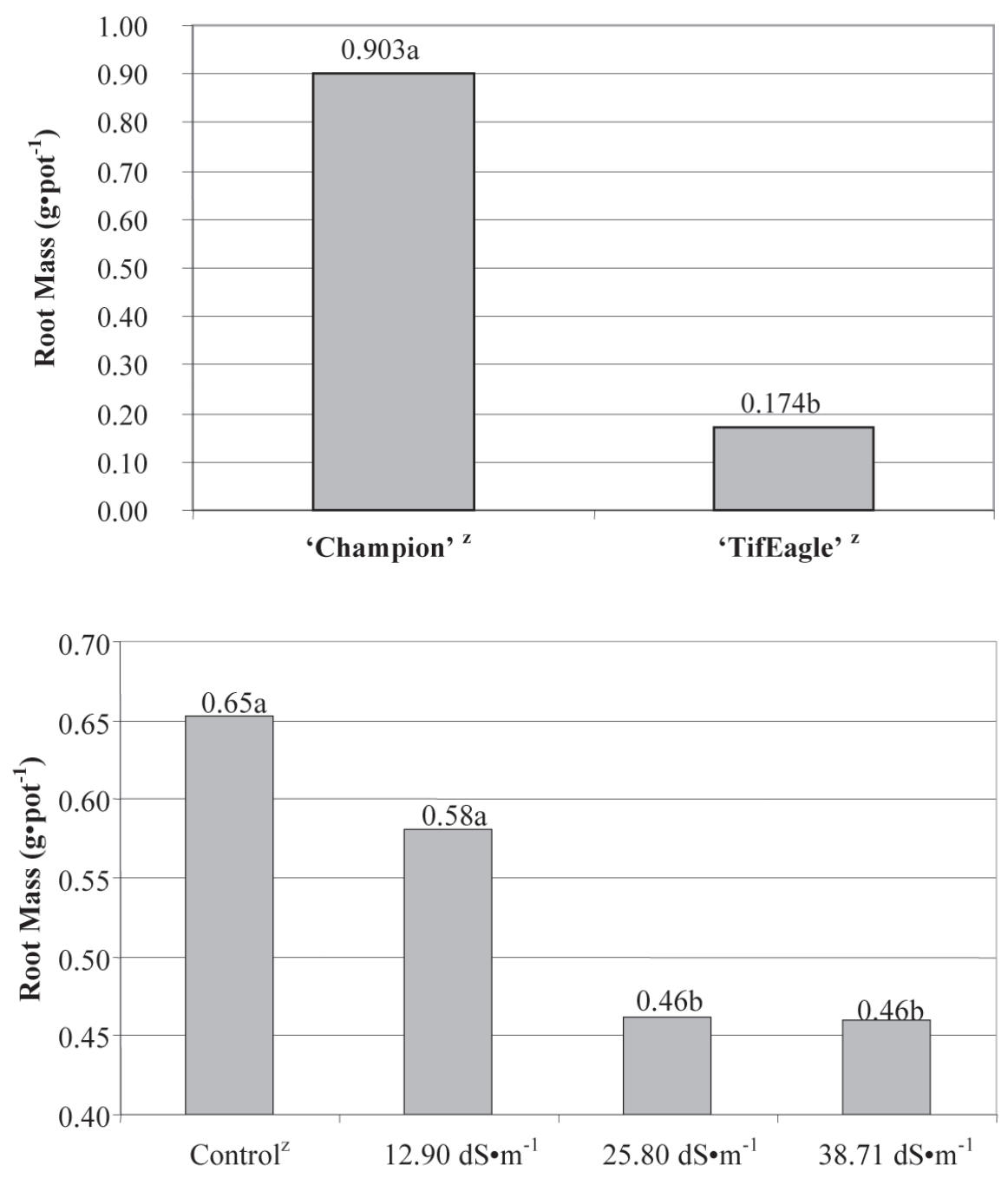

cultivars (TE treated and nontreated) were noted as salinity treatments increased.

From this greenhouse study, the two bermudagrass cultivars responded differently when exposed to moderate levels of $\mathrm{NaCl}$. Future studies could focus on other ultradwarf bermudagrass cultivars, such as 'MiniVerde', 'MS-Supreme', 'Tifdwarf', and 'FloraDwarf'. Also, salinity levels should be reduced to focus on TE's effect on TQ at lower $\mathrm{NaCl}$ levels as 25.80 and 38.71 $\mathrm{dS} \cdot \mathrm{m}^{-1}$ were toxic to both cultivars. Also, initiating TE applications before salt stress becomes prevalent may improve the grasses response to increased salinity. Finally, rather than applying $\mathrm{NaCl}$ daily, cycling fresh water weekly may also improve turfgrass response.
Fig. 5. Combined root mass (g) of 'Champion' and 'TifEagle' bermudagrass following four applications of trinexapac-ethyl at $0.02 \mathrm{~kg} \cdot \mathrm{a}$.i./ha when exposed to $0,12.90,25.80$, and $38.71 \mathrm{dS} \cdot \mathrm{m}^{-1}$ of sodium chloride.

${ }^{\mathrm{z}}$ Mean data points followed by the same letter are not significantly different at $p \leq 0.05$.

Fig. 6. Comparison of 'Champion' and 'TifEagle' bermudagrass root weight when exposed to 0 , $12.90,25.80$, and $38.71 \mathrm{dS} \cdot \mathrm{m}^{-1}$ of sodium chloride with and without trinexapac-ethyl.

${ }^{\mathrm{z}}$ Mean data points followed by the same letter are not significantly different at $p \leq 0.05$.
Fig. 7. Combined root mass (g) of 'Champion' and 'TifEagle' bermudagrass following 10 weeks of salinity application at $12.90,25.80$, and 38.71 $\mathrm{dS} \cdot \mathrm{m}^{-1}$ of sodium chloride.

$\overline{{ }^{z} \text { Within salinity levels, mean data points followed by }}$ the same letter are not significantly different.

\section{Literature Cited}

Ackerson, R.C. and V.B. Youngner. 1975. Responses of bermudagrass to salinity. Agron. J. 67:678-681.

Baldwin, C.M., H. Liu, L. B. McCarty, W.L. Bauerle, and J.E. Toler. 2005. Aluminum tolerance of warm-season turfgrasses. Intl. Turfgrass Res. J. 10:811-817. 
Table 1. Sodium concentration $\left(\mathrm{dS} \cdot \mathrm{m}^{-1}\right)$ in two bermudagrass cultivars shoot and root tissue treated with and without trinexapac-ethyl and exposed to 0 , 12.90 , and $25.80 \mathrm{dS} \cdot \mathrm{m}^{-1}$ of sodium chloride.

\begin{tabular}{|c|c|c|c|c|c|c|}
\hline \multirow{2}{*}{ Turf } & \multicolumn{6}{|c|}{ Na conen $\left(\mathrm{dS} \cdot \mathrm{m}^{-1}\right)$} \\
\hline & \multicolumn{3}{|c|}{ Root tissue } & \multicolumn{3}{|c|}{ Shoot tissue } \\
\hline$\overline{\mathrm{PT}^{\mathrm{z}}}$ & $1.95 \mathrm{a}^{\mathrm{y}}$ & 6.53 & $18.06 \mathrm{a}$ & 3.05 & 31.92 & $52.70 \mathrm{a}$ \\
\hline NPT & $1.72 \mathrm{a}$ & 7.00 & $11.61 \mathrm{~b}$ & 3.97 & 25.26 & $37.69 \mathrm{~b}$ \\
\hline NPC & $0.93 \mathrm{~b}$ & 7.43 & $12.88 \mathrm{~b}$ & 3.62 & 28.74 & $53.77 \mathrm{a}$ \\
\hline LSD & 0.42 & 1.93 & 4.32 & 1.48 & 7.38 & 7.28 \\
\hline$p$ value & $0.01^{x}$ & 0.77 & 0.02 & 0.53 & 0.13 & 0.01 \\
\hline
\end{tabular}

${ }^{2} \mathrm{PT}=$ 'TifEagle' with trinexapac-ethyl, $\mathrm{PC}=$ 'Champion' with trinexapac-ethyl, NPT $=$ 'TifEagle' without trinexapac-ethyl, NPC $=$ 'Champion' without trinexapac-ethyl.

${ }^{y}$ Values within a column followed by the same letter are not significantly different at $P \leq 0.05$ by protected LSD.

${ }^{x}$ Indicates statistical difference at $p \leq 0.05$.

Table 2. Phosphorus (P) and potassium (K) concentration in shoot and root tissue of 'Champion' and 'TifEagle' bermudagrass with and without exposure to 12.90 and $25.80 \mathrm{dS} \cdot \mathrm{m}^{-1}$ of sodium chloride.

\begin{tabular}{|c|c|c|c|c|c|c|c|c|c|c|c|c|}
\hline \multirow[b]{3}{*}{ Turf } & \multicolumn{6}{|c|}{ P concn $(\%)$} & \multicolumn{6}{|c|}{ K concn $(\%)$} \\
\hline & \multicolumn{3}{|c|}{ Root tissue } & \multicolumn{3}{|c|}{ Shoot tissue } & \multicolumn{3}{|c|}{ Root tissue } & \multicolumn{3}{|c|}{ Shoot tissue } \\
\hline & Control & 12.90 & 25.80 & Control & 12.90 & 25.80 & Control & 12.90 & 25.80 & Control & 12.90 & 25.80 \\
\hline$\overline{\mathrm{PT}^{\mathrm{z}}}$ & 0.11 & $0.16 \mathrm{a}^{\mathrm{y}}$ & 0.11 & 0.60 & 0.45 & 0.37 & 0.39 & $0.18 \mathrm{bc}$ & $0.09 \mathrm{~b}$ & 2.76 & $1.47 \mathrm{~b}$ & $0.80 \mathrm{c}$ \\
\hline NPT & 0.10 & $0.10 \mathrm{~b}$ & 0.13 & 0.61 & 0.46 & 0.35 & 0.33 & $0.15 \mathrm{c}$ & $0.11 \mathrm{ab}$ & 3.03 & $1.62 \mathrm{a}$ & $0.93 \mathrm{~b}$ \\
\hline NPC & 0.10 & $0.11 \mathrm{~b}$ & 0.11 & 0.62 & 0.47 & 0.38 & 0.41 & $0.23 \mathrm{a}$ & $0.12 \mathrm{a}$ & 3.13 & $1.62 \mathrm{a}$ & $0.98 \mathrm{ab}$ \\
\hline LSD & 0.02 & 0.04 & 0.03 & 0.08 & 0.05 & 0.07 & 0.12 & 0.04 & 0.03 & 0.31 & 0.09 & 0.10 \\
\hline$p$ value & $0.22^{x}$ & 0.02 & 0.15 & 0.48 & 0.90 & 0.36 & 0.19 & 0.01 & 0.04 & 0.10 & 0.01 & 0.01 \\
\hline
\end{tabular}

${ }^{2} \mathrm{PT}=$ 'TifEagle' with trinexapac-ethyl, $\mathrm{PC}=$ 'Champion' with trinexapac-ethyl, NPT = 'TifEagle' without trinexapac-ethyl, NPC $=$ 'Champion' without trinexapac-ethyl.

yValues within a column followed by the same letter are not significantly different at $P \leq 0.05$ by protected LSD.

'Indicates statistical difference at $p \leq 0.05$.

Table 3. Magnesium $(\mathrm{Mg})$ and calcium (Ca) concentration in shoot and root tissue of 'Champion' and 'TifEagle' bermudagrass with and without exposure to 12.90 and $25.80 \mathrm{dS} \cdot \mathrm{m}^{-1}$ of sodium chloride.

\begin{tabular}{|c|c|c|c|c|c|c|c|c|c|c|c|c|}
\hline \multirow{2}{*}{ Turf } & \multicolumn{6}{|c|}{ Mg concn $(\%)$} & \multicolumn{6}{|c|}{ Ca concn $(\%)$} \\
\hline & \multicolumn{3}{|c|}{ Root tissue } & \multicolumn{3}{|c|}{ Shoot tissue } & \multicolumn{3}{|c|}{ Root tissue } & \multicolumn{3}{|c|}{ Shoot tissue } \\
\hline$\overline{\mathrm{PT}^{\mathrm{z}}}$ & 0.18 & 0.06 & 0.06 & $0.22 \mathrm{a}^{\mathrm{y}}$ & 0.10 & $0.08 \mathrm{a}$ & 0.18 & 0.12 & $0.18 \mathrm{a}$ & $0.27 \mathrm{a}$ & $0.22 \mathrm{a}$ & $0.23 \mathrm{a}$ \\
\hline NPT & 0.10 & 0.08 & 0.04 & $0.17 \mathrm{~b}$ & 0.09 & $0.05 \mathrm{~b}$ & 0.16 & 0.11 & $0.11 \mathrm{~b}$ & $0.19 \mathrm{c}$ & $0.14 \mathrm{~b}$ & $0.13 \mathrm{~b}$ \\
\hline NPC & 0.12 & 0.06 & 0.04 & $0.19 \mathrm{ab}$ & 0.09 & $0.07 \mathrm{~b}$ & 0.20 & 0.11 & $0.12 \mathrm{~b}$ & $0.21 \mathrm{bc}$ & $0.12 \mathrm{~b}$ & $0.15 \mathrm{bc}$ \\
\hline LSD & 0.07 & 0.02 & 0.02 & 0.03 & 0.02 & 0.03 & 0.05 & 0.02 & 0.04 & 0.05 & 0.07 & 0.05 \\
\hline$p$ value & $0.94^{x}$ & 0.21 & 0.63 & 0.01 & 0.68 & 0.04 & 0.15 & 0.66 & 0.01 & 0.01 & 0.04 & 0.01 \\
\hline
\end{tabular}

${ }^{2} \mathrm{PT}=$ 'TifEagle' with trinexapac-ethyl, $\mathrm{PC}=$ 'Champion' with trinexapac-ethyl, NPT $=$ 'TifEagle' without trinexapac-ethyl, NPC $=$ 'Champion' without trinexapac-ethyl.

yValues within a column followed by the same letter are not significantly different at $P \leq 0.05$ by protected LSD.

${ }^{\mathrm{x}}$ Indicates statistical difference at $p \leq 0.05$.

Bunnell, B.T., L.B. McCarty, and W.C. Bridges. 2005. TifEagle bermudagrass response to growth factors and mowing heights when grown at various hours of sunlight. Crop Sci. 45:575-581.

Carrow, R.N. and R.R. Duncan. 1998. Salt-affected turfgrass sites: Assessment and management. Ann Arbor Press, Inc. Chelsea, Mich.

Carrow, R.N., D.V. Waddington, and P.E. Reike. 2001. Turfgrass soil fertility and chemical problems: Assessment and management. Ann Arbor Press, Inc. Chelsea, Mich.

Duncan, R.R. and R.N. Carrow. 2000. Soon on golf courses: New seashore paspalums. Golf Course Mgt. 68(5):11-15.

Dudeck, A.E., S. Singh, C.E. Giordiano, T.A. Nell, and D.B. McConnell. 1983. Effects of sodium chloride on Cynodon turfgrasses. Agron. J. 75:927-930.

Dudeck,A.E. and C.H. Peacock. 1993. Salinity effects on growth and nutrient uptake of selected warmseason turf. Intl. Turfgrass Res. J. 7:680-686.

Erickson, J.E, J.L. Cisar, G.H. Snyder, and J.C. Volin. 2005. Phosphorus and potassium leaching under contrasting residential landscape models established on a sandy soil. Crop Sci. 45:546-552.

Ervin, E.H. and A.J. Koski. 2001. Kentucky bluegrass growth responses to trinexapac-ethyl, traffic, and nitrogen. Crop Sci. 41:1871-1877.

Fagerness, M.J. and D. Penner. $1998 .{ }^{14} \mathrm{C}$-Trinexapac- ethyl absorption and translocation in Kentucky bluegrass. Crop Sci. 38:1023-1027.

Fagerness, M.J. andF.H.Yelverton. 2001.Plant growth regulator and mowing height effects of seasonal root growth of Penncross creeping bentgrass. Crop Sci. 41:1901-1905.

Fagerness, M.J., D.C. Bowman, F.H. Yelverton, and T.W. Ruffy, Jr. 2004. Nitrogen use in Tifway bermudagrass, as affected by trinexapac-ethyl. Crop Sci. 44:595-599.

Harivandi A., J.D. Bulter, and L. Wu. 1992. Salinity and turfgrass culture, p.208-230. In: D.V. Waddington etal.(eds.). Turfgrass.ASA-CSSA-SSSA Agron. Monogr. 32.

Lee, G., R.R. Duncan, and R.N. Carrow. 2004. Salinity tolerance of seashore paspalum ecotypes: shoot growth responses and criteria. HortScience 39(5):1143-1147.

Marcum, K.B., S.J. Anderson, and M.C. Engelke. 1998. Salt gland ion secretion:A salinity tolerance mechanism among five zoysiagrass species. Crop Sci. 38:806-810.

Marcum, K.B. 1999. Salinity tolerance in turfgrasses, p.891-905. In: M. Pessarakli (ed.). Handbook of plant and crop stress. 2nd ed. Marcel Dekker, New York.

Marcum, K.B. 2002. Growth and physiological adaptations of grasses to salinity stress, p. 623-635. In:
M. Pessarakli (ed.). Handbook of plant and crop physiology. 2nd ed. Marcel Dekker, New York.

Marcum, K.B., G. Wess, D.T. Ray, and M.C. Engelke. 2003. Zoysiagrass, salt glands, and salt tolerance. USGA Turfgrass Environ. Res. Online 2(14):1-6.

McCarty, L.B., J.S. Weinbrecht, J.E. Toler, and G.L. Miller. 2004. St. Augustinegrass response to plant growth retardants. Crop Sci. 44:1323-1329.

McCarty, L.B. 2005. Best golf course management practices. 2nd ed. Prentice-Hall Inc., Upper Saddle River, N.J.

Qian, Y.L., M.C. Engelke, and M.J.V. Foster. 2000. Salinity effects on zoysiagrass cultivars and experimental lines. Crop Sci. 40:488-492.

SAS Institute Inc. 1999. SAS version 8.0. SAS Inst., Cary, N.C.

Shepard, D. 2002. Users drive research into new growth regulator applications. Turfgrass Trends 11(4):T10-T12, T14.

Steinke, K. and J.C. Stier. 2003. Nitrogen selection and growth regulator applications for improving shaded turf performance. Crop Sci. 43:1399-1406.

Zhang, X., E.H. Ervin, and R.E. Schmidt. 2003. Plant growth regulators can enhance the recovery of Kentucky bluegrass sod from heat injury. Crop Sci. 43:952-95. 